\title{
Alcohol abuse-induced health and psychosocial losses among residents of social care institutions
}

Jolanta Karyś ${ }^{1}{ }_{\mathrm{AD}}$, Dorota Rębak ${ }_{\mathrm{E}}$, Tomasz Karyśs ${ }_{\mathrm{C}}$, Bogumiła Kowalczyk - Sroka ${ }_{\mathrm{F}}$, Ewa Dudek ${ }_{\mathrm{B}}$

${ }^{1}$ Higher School of Economics, Law and Medical Sciences

${ }^{2}$ Faculty of Health Sciences, Jan Kochanowski University in Kielce

${ }^{3}$ Marshal's Office, Świetokrzyskie Province

\begin{abstract}
Introduction. Alcoholism is one of the most serious social issues of modern times. In Poland, the importance of problems resulting from alcohol abuse or misuse is significant, both in the context of health, economic and social consequences.

Aim. The aim of the present study was to determine health and psychosocial losses of alcohol abuse among residents of social care institutions.

Material and methods. A diagnostic survey was conducted using the author's questionnaire. The study was carried out among 30 residents of the nursing home in Kielce. The inclusion criterion was alcohol abuse.

Results. In the study group, the largest group consisted of divorced residents $-66.67 \%$. All of them admitted that alcohol abuse was the cause of divorce. Lack of contact with families was declared by $56.67 \%$ of respondents. None of the residents (100\%) was visited by friends from outside the nursing home. Psychotic symptoms (hallucinations after alcohol) were found in $73.33 \%$ of residents. Somatic symptoms (headache, stomachache) and sleep disorders were confirmed by $90 \%$ of respondents. Attempts to cope with addiction were undertaken by $76.67 \%$ of residents; $73.33 \%$ declared their readiness to limit alcohol consumption.

Conclusions. Adverse consequences of alcohol abuse involve somatic, family-related, social and emotional spheres. Respondents have large deficits in social relations due to long-term alcohol abuse and excessive preoccupation with alcohol. Alcohol in nursing homes fills the time, eliminates the feeling of loneliness, kills boredom and helps to forget about problems. Residents abusing alcohol on a daily basis feel alienated and have low self-esteem.
\end{abstract}

Key words: alcoholism, addiction, resident, psychosocial deficits

\section{Introduction}

Alcoholism is one of the most serious dangers of modern times. Considering alcohol abuse-associated health and social risks, the importance of problems resulting from alcohol abuse or misuse is significant, both in the context of health, economic and social consequences.

Alcohol accompanies man since the dawn of time and its nature has always been ambiguous. In our reality, alcohol ambivalence is felt particularly intensively. On the one hand, alcohol is associated with celebrations and closeness of friends, on the other hand, with enslavement, degeneration, breakdown of family life or even death [1].

Healthy lifestyle is one of the most difficult tasks of modern times. Nowadays people live quickly and do not pay attention to consequences. Because of hasty and stressful life, some individuals are not capable of coping with themselves and permanent tension. Weaker individuals reach for psychoactive substances, which seemingly calm them down enabling further functioning. Alcohol is the most popular and widely available psychoactive substance.

Alcohol addiction is a disease that ruins alcoholics physically, emotionally, spiritually and intellectually. Mental addiction consists in the need of drinking alcohol to improve mental and physical state. Alcohol causes many various social and health problems, whose extent is strictly connected with the amount of alcohol consumed.

The causes of alcoholism are not known; anyone can become an alcoholic, irrespective of the strength of alcohol drunk. An alcoholic is someone with drinking compulsion and without control over the amount of alcohol consumed. Those who abuse alcohol give many reasons for drinking and do not accept the fact of being addicted while intoxicated. Most commonly, they say that "they drink because nobody understands them", "they have problems" 
or „lost their jobs”, etc. The truth is that alcoholics drink because of one reason- they are addicted and feel the compulsive need to consume further alcohol doses

Alcohol addiction means no control over the amount of alcohol drunk and frequency of drinking. Consumption of usually large doses of alcohol is caused by mental and somatic compulsion and cannot be controlled; however, cessation and abstinence are possible [2].

This condition is characterized by behavioural changes and their sequels, including continuous or periodic compulsion of abusing alcohol to experience its mental effects or avoid the symptoms resulting from its lack. The change in tolerance can although does not have to accompany this phenomenon. Man can become addicted simultaneously to alcohol and other psychoactive substances (ingested, inhaled or injected) [1].

Alcoholic disease causes changes in emotional, physiological and social spheres. Addicts can manipulate their closest circle to be able to follow the rule - I drink but others suffer the consequences. It appears that alcoholism is irreversible, as addicts can never again drink in a controllable way. The only way to stop the disease is complete abstinence and total changes in life philosophy [3].

Alcoholism is one of the most serious social problems of modern times. Alarming data regarding increased alcohol consumption among young people, significantly decreased age of alcohol initiation, alcohol-related problems considered in a wider context of family abuse, alcohol-induced diseases, damage caused by drinking teenagers and lonely individuals resulted in an increasing interest in prevention of alcoholism as well as support for addicts and their relatives.

\section{Aim}

The aim of the study was to determine health and psychosocial adverse consequences of alcohol abuse among residents of a nursing home.

\section{Material and methods}

A diagnostic survey was carried out using the author's questionnaire. The questionnaire contained 33 closed and half-opened questions regarding socio-demographic data and a set of questions about the health conditions and psychosocial situations of respondents.

The study was conducted in the nursing home in Kielce. The inclusion criterion was alcohol abuse.
The group of 30 residents selected for the study consisted of 27 men $(90 \%)$ and 3 women $(10 \%)$.

The largest group consisted of residents above the age of 60 years $-56.67 \%$. The other age groups were as follows: 9 individuals aged 51-60 years $(30 \%)$ and 3 individuals (10\%) aged $41-50$ years. The smallest group consisted of residents aged 3140 years

\section{(1- 3.33\%).}

Sixty percent of residents had vocational education, $20 \%$ - secondary education and $16.67 \%$ - primary education. The smallest percentage of respondents had higher education $-3.33 \%$.

\section{Results}

Biological, mental (including emotional) and social spheres of alcohol abusers were analysed.

The majority of the study population were divorced $-66.67 \%, 16.67 \%$ were widowers and $13.33 \%$ were single. Only one resident was married, which constituted $3.33 \%$ of the study group.

Twenty of 30 individuals were divorced; all of them $(100 \%)$ confirmed that alcohol abuse was the cause of getting divorced.

Lack of contact with families was declared by $56.67 \%$ (17) of respondents. The majority (25; $83.33 \%$ ) had children; the remaining 5 (16.67\%) were childless. Fourteen (46.67\%) residents had no contact with children, $10(33.33 \%)$ contacted children several times a year, $1(3.33 \%)$ several times a month and the remaining 5 residents $(16.67 \%)$ had no children.

The reasons given by respondents were alcohol use, reluctance of children and of respondents themselves.

None of the respondents $(100 \%)$ was visited by friends from outside the nursing home.

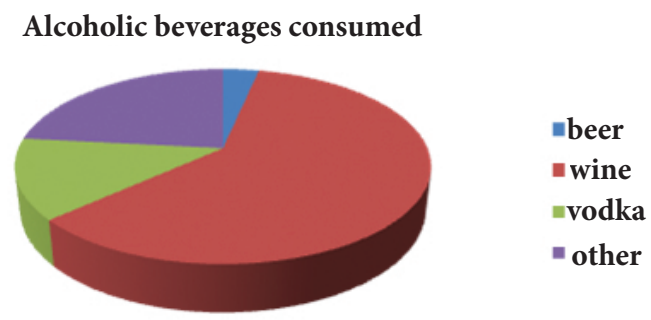

Fig.1. Alcoholic beverages consumed 
The respondents have abused alcohol for 20 years (73.33\%); their alcohol initiation was at the age of $15-20$ years $(93.33 \%)$.

The most commonly consumed alcohol was wine- $60 \%$. Vodka was drunk by $13.33 \%$ of respondents; one respondent $(3.33 \%)$ preferred beer while $23.33 \%$ preferred other alcohols (alcoholic cocktails).

The frequency of alcohol consumption was as follows: $13(43.33 \%)$ respondents drank 2-3 times a week, 9(30.00\%) - more than 4 times a week, $6(20 \%)$ - once or twice a week. Two respondents (6.67\%) drank alcohol less than once a week.

The effects of alcohol on mental and physical state of respondents were analysed. In 14 respondents (46.67\%) alcohol caused joy, in $8(26.67 \%)$ nervousness and in $1(3.33 \%)$ enhanced courage. Seven (23.33\%) respondents reported sleepiness and one respondent - calmness.

Alcohol abuse of parents was confirmed by 5 respondents (16.67\%); in four cases - fathers and in one case - mother. The majority (80\%) denied that siblings abused alcohol, $20 \%$ confirmed this fact.

Benefits and losses caused by alcohol abuse assessed by respondents were the key element. The losses regarded health, family, money, job and friends. The alcohol-related benefits pointed out by residents were passing spare time - 76.67\%, improving well-being $-20 \%$, enhancing courage $-3.33 \%$.

Psychosomatic symptoms in the form of visual and auditory hallucinations on alcohol withdrawal were observed in $73.33 \%$ of respondents. In the course of withdrawal syndrome, $56.67 \%$ of respondents experienced seizures indicating alcohol-related epilepsy and all the respondents reported severe tremors, particularly of upper limbs. Somatic symptoms (headaches and stomachaches) and sleep disorders associated with alcohol abuse were confirmed by $90 \%$ of respondents whereas nausea and vomiting by $86.67 \%$.

Moreover, $83.33 \%$ of respondents (25) were hospitalized due to alcohol abuse. Over half of respondents (60\%) confirmed problems at work due to alcohol drinking. Attempts to deal with addiction were made by $76.67 \%$ of respondents, i.e. attempts to maintain abstinence, detoxification treatment, use of medicines, forced abstinence (imprisonment). Readiness to limit drinking or staying sober was declared by $73.33 \%$ of respondents, each. Those individuals expected that sobriety meant better, happier life as well as hope to rejoin families, have higher respect for themselves and less severe health problems.

Sixty percent of respondent did not think about their attitude towards themselves; $40 \%$ had negative attitudes and nobody had positive attitudes. All the respondents decided that alcohol was a means to forget about problems.

The causes of being in the nursing home pointed out by residents were as follows: homelessness, lack of care, loss of parents (no place to live), accidents - lack of family support, rejection by partners or family, and alcohol abuse.

According to respondents, life without alcohol would be better and happier and would enable to regain health, family and self-esteem. Some respondents could not imagine life without alcohol; some would like to stop drinking but did not think what their life without alcohol would be.

\section{Discussion}

There are many reasons why the elderly get to social care institutions. Our findings demonstrate that the majority of respondents ended up in the nursing home due to earlier alcohol abuse. The respondents believe that they would be homeless and left without any help, if not for the nursing home. The majority was divorced $(66.67 \%)$ and all residents confirmed that alcohol abuse was the reason of divorce. Moreover, they admitted to long-term drinking, which is reflected in the study results.

Our findings demonstrate that alcohol abuse regards $5-12 \%$ of men and $1-2 \%$ of women above the age of 60 years. It is estimated that the percentage of individuals above the age of 65 years with alcohol problems is $10 \%$ in men and $3-5 \%$ in women [1]. In our study, 
the largest group consisted of residents $>60$ years of age $-56.67 \%$; $30 \%$ were aged $51-60$ years and 10\% - $41-50$ years. The above shows that $40 \%$ of individuals were of the productive age and that alcohol was likely to be responsible for their stay in the nursing home, hence social support.

Sixty percent of respondents had vocational education, $16.67 \%$ primary and $20 \%$ secondary education; only one individual had higher education. The above percentages are likely to evidence low awareness and knowledge regarding alcohol abuse and ways to free them of addiction. The low level of awareness and criticism is also affected by long-term alcohol abuse and resultant alcohol degeneration.

Our findings reveal that the respondents have abused alcohol for 20 years $(73.33 \%)$; the majority of them had their alcohol initiation at the age of $15-20$ years (93.33\%). According to various studies, children/teenagers had their contact with alcohol before coming of age. Another alarming factor is that children/ teenagers confirm they were intoxicated with alcohol before reaching the age of 18 years [4]. Wine and alcoholic cocktails were the most common alcohols consumed by the respondents ( $60 \%$ and $23.33 \%$, respectively). These are the cheapest alcohols, which is associated with the material condition of residents.

In Poland, the rate of alcohol-related hospitalizations (including psychoses) was $6 \%$ higher in 2008 compared to the previous year, i.e. 277/10 000 individuals, and varied in individual provinces [5]. In our study population, $73.33 \%$ of respondents had acute psychotic symptoms and $76.67 \%$ had alcoholic palimpsests. Seizures were confirmed by $56.67 \%$ of respondents. According to literature data, about $20-30 \%$ of alcohol addicts hale seizures and psychotic symptoms [5]. Alcohol abuse-associated hospitalizations were confirmed by $83.33 \%$ of respondents. One of the withdrawal symptoms, i.e. tremor (particularly of upper limbs), was confirmed by $100 \%$ of respondents. Therefore, it could be hypothesized that the symptoms mentioned above indicate advanced complications of alcohol addiction.
In recent years, the elderly above the age of 65 constituted slightly more than $1 \%$ of patients treated due to alcoholic psychoses and alcohol addiction in stationary institutions and slightly more than $2 \%$ of patients treated in detoxification clinics [6].

Researchers have been studying the issue of addiction heredity for years. Their findings are neither clear nor explicit. An addiction paradigm is still being searched for. However, based on available data, it can be seen that the majority of researchers are increasingly in favour of the thesis that the tendency to addiction is inherited. The other concepts point to social heredity regarding behaviour patterns of the closest environment in the process of internalisation. The family with at least one addicted individual substantially increases the risk of addiction [7,8,9]. Half of adult alcoholics come from families with alcoholic problems $[10,11]$. Our findings correspond to the above data; $16.67 \%$ of respondents confirmed alcohol abuse of parents and $20 \%$ admitted that their siblings abused alcohol. It should be remembered that, irrespective of heredity of social behaviours, addictions develop due to long-term and intensive drinking, which is not included in the definition of genetic heredity [12].

Findings regarding relationships with children are surprising; $83.33 \%$ of respondents have children yet almost half have no contacts with them, which undoubtedly implies alienation and low self-esteem of respondents. Only 1.3 of residents contacts children several times a year. Analysis of contacts with families demonstrates that 43.335 of respondents have such contact and the remaining 56.67\% have no such contacts. None of the respondents has friends from outside the nursing home. The findings show that alcohol abuse is likely to be the reason (although perhaps not the only one).

Moreover, $100 \%$ of respondents confirmed that alcohol is a means to forget about problems or troubles and that the benefits of alcohol abuse include passing spare time (76.67\%) and improved well-being (20\%). On the other hand, negative attitudes towards 
themselves were admitted by $40 \%$ of respondents while $60 \%$ did not thing about this issue, which can be considered a protective mechanism. Consumption of alcohol can be an attempt to "deafen" problems, "escape" from them, from the feeling of pointlessness, anomy and low self-esteem. Health problems, lower well-being, inability to cope with the new situation and boredom are the causes why the elderly reach for alcohol $[13,14,15]$, which is confirmed by our findings.

Further exploration of the study results shows that health losses due to pathological alcohol use were found in $90 \%$ of respondents; $60 \%$ lost their families because of alcohol problems; financial losses were confirmed by $30 \%$ and loss of friends by $20 \%$ of respondents; 23.335 lost their jobs due to alcohol and 60\% confirmed problems at work caused by alcohol abuse. The above results are fully consistent with the findings of other authors demonstrating alcoholic deprivations in all spheres of human life.

Moreover, $73.33 \%$ of respondents would like to limit drinking and stay sober. The majority of them believe that life without alcohol would be better and would enable them to regain their families. For some reasons, the above declarations are not fulfilled, most likely due to lack of motivation, or emotional support of friends or goals in life. Possible formal declarations should also be considered as many respondents abused alcohol living with their families and even the perspective of loosing them was not sufficiently motivating to stop drinking. Some respondents state that they cannot imagine their lives without alcohol, which evidences their lack of hope for better quality of life, permanent loss of sense and existential emptiness $[16,17]$.

\section{Conclusions}

1. Alcohol abuse -associated losses among respondents involve somatic, family, social and emotional spheres.
2. Respondents show high deficits in social relations due to long-term alcohol abuse and focusing on this substance.

3. Alcohol in nursing homes largely fills time, eliminates the feeling of loneliness, kills boredom and helps to forget abort problems and troubles.

4. Residents abusing alcohol on a daily bases feel alienated and have low self-esteem.

\section{References}

1.Woronowicz B. Uzależnienia. Warszawa : Media Rodzina \& Parpamedia; 2009.

2. Woronowicz B. Na zdrowie. Jak poradzić sobie z uzależnieniem od alkoholu. Warszawa : Wydawnictwo Edukacyjne PARPAMEDIA; 2008.

3. Krawentek M. Zgubne skutki picia wódki - co alkohol robi z mózgiem [Internet] 2009 [cited 2013 Jan 29]. Available from: http://neuroskoki

4. Anderson P, Baumberg B. Alkohol w Europie. Perspektywa zdrowia publicznego Raport dla Komisji Europejskiej - Podsumowanie. Alkoholizm i Narkomania 2006; 19(2): 121-137.

5. Narodowy Program Profilaktyki i Rozwiązywania Problemów Alkoholowych na lata 2011-2015 opracowany na podstawie art. 3 ust. 3 pkt 1 ustawy z dnia 26 października 1982 r. o wychowaniu w trzeźwości i przeciwdziałaniu alkoholizmowi Dz. U., 2007, Nr 70, poz. $473 \mathrm{z}$ późn. $\mathrm{zm}$.

6. Woronowicz BT. Alkoholizm wieku podeszłego [Internet] [cited 2014 Feb 16]. Available from: http://alkoholizm

7. Oakes KE. Purpose in life: A Mediating Variable Betwenn Involvement in Alcoholics Anonymous and Long- Term Recovery. Alcoholism Treatment Quarterly 2008; 26: 450-463.

8. Donovan D, Mattson M, Cisler R, Langabaug R, Zweben A. Quality of life as an outcome measurement in alcoholism treatment research. Journal of life in alcohol-dependent subjects-a review. Quality of life Research 2005; 8(3): 255-261.

9. Morgan MY, Landron F, Lehert P. Imperovement in quality of life after treatment for alcohol dependence with acomprosate and psychosocial support. Alcoholism, Clinical and Experimental Research 2004; 28: 64-77.

10. Sztander W. Poza kontrolą. Warszawa: Instytut Psychologii Zdrowia. Polskie Towarzystwo Psychologiczne; 2006.

11. Tobiasz - Adamczyk. Wybrane aspekty socjologiczne wieku starszego [Internet] [cited 2014 Feb 02]. Available from: http://wwwswiatproblemow

12. Wojdyło E. Ile możesz wypić. Gdańsk: GWP; 2010.

13. Dane Państwowej Agencji Rozwiązania Problemów 
Alkoholowych [Internet] [cited 2014 Jan 28].Available from: www.parpa.pl 14. Kaczmarczyk I. Choroba godności. Terapia uzależnień i współuzależnienia. Fundacja „Zdrowie-Trzeźwość" PARPA, 2007; 2: 5-8.

15. Smith KW, Larson MJ. Quality of life Assessnents by Adutt Substancje Abusers Receiving. Publicly Funded Treatment in Massachusetts. American Journal of Drug and Alcohol Abous 2003; 29(2): 323-335.

16. Chodkiewicz J. Ocena jakości życia alkoholików przed i po terapii odwykowej. Co zmienia się w czasie leczenia? Warszawa : Polskie Towarzystwo Psychiatryczne. Instytut Psychiatrii i Neurologii; 2012.148. Alkoholizm i narkomania 2012; 25(2): 133-150.
17. Grabowski A. Stale aktualny problem zdrowotny społeczeństwa Polskiego. Aktywność Samorządu w zakresie profilaktyki alkoholowej. Nowiny Lekarskie 2005;74 (2): 244-250.

\section{Correspondence address:}

Jolanta Karyś

Świętokrzyskie Centrum Psychiatrii, Oddział XIII

Morawica ul. Spacerowa 5, 26 - 026 Morawica

Tel. 693156363

E-mail: j.a.karys@interia.pl 